University of Nebraska - Lincoln

DigitalCommons@University of Nebraska - Lincoln

2019

\title{
A Red-State View of Religious Liberty and Nondiscrimination Protection for LGBT People
}

Kelsy Burke

Emily Kazyak

Follow this and additional works at: https://digitalcommons.unl.edu/sociologyfacpub

Part of the Family, Life Course, and Society Commons, and the Social Psychology and Interaction Commons

This Article is brought to you for free and open access by the Sociology, Department of at DigitalCommons@University of Nebraska - Lincoln. It has been accepted for inclusion in Sociology Department, Faculty Publications by an authorized administrator of DigitalCommons@University of Nebraska - Lincoln. 


\title{
A Red-State View of Religious Liberty and Nondiscrimination Protection for LGBT People
}

\author{
Kelsy Burke and Emily Kazyak
}

\begin{abstract}
D espite the legalization of same-sex marriage in 2015, two issues remain contentious in national debates about LGBT rights: employment non-discrimination and religious liberty. About half of all states in the U.S. offer protection against workplace discrimination on the basis of sexual orientation and gender identity. Twenty-one states have religious exemption laws that offer protection for people to refuse services based on their religious beliefs. Debates about such religious exemption laws as they relate to LGBT discrimination have become increasingly common. For instance, a Mississippi law (HB 1523)_passed in April 2016 and implemented in October 2017 after a series of court appeals - protects persons who have "the sincerely held religious beliefs" that marriage "should be recognized as the union of one man and one woman" and that gender "refers to an individual's immutable biological sex as objectively determined by anatomy and genetics at time of birth" and choose not to provide services, including housing and employment, to LGBT people. Courts and state legislatures are deciding whether and to what degree religious exemption laws should allow people to make decisions in their work environment that uphold their religious-based opposition to gay, lesbian, and transgender identities.
\end{abstract}

Published in Contexts, Vol. 18, Issue 3 (Summer 2019), pp. 63-65.

DOI 10.1177/1536504219864962.

Copyright $\odot$ American Sociological Association. Used by permission. 
How do these issues play out in a red state like $\mathrm{Ne}$ braska? Nebraska is one of 26 states that do not have an employment non-discrimination law for LGBT people. Bills that would add sexual orientation and gender identity to the state's legally protected classes have been debated in the state legislature for the past 20 years, but have always failed. The discussion of employment non-discrimination laws often invokes the importance of religion and conservative values in Nebraska. In voicing his opposition, one Nebraskan senator said "people are moving back to Nebraska because of its conservative values" and argued that an employment non-discrimination law "would be used as a sword against people with traditional understandings of marriage and sexuality." Another Nebraskan senator agreed, insisting that such a law would "foster widespread discrimination against people of faith and those with traditional understandings of marriage and sexuality." Indeed, even though Nebraska is among the 29 states without a religious exemption law, religious exemption is de factothere are no protections for LGBT people.
Laws to protect gay men and

lesbians from job discrimination

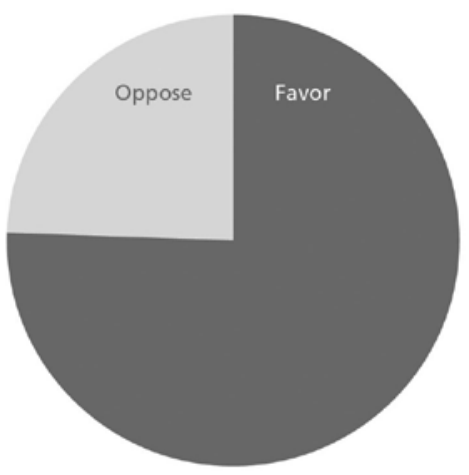

Laws to protect transgender individuals from job discrimination

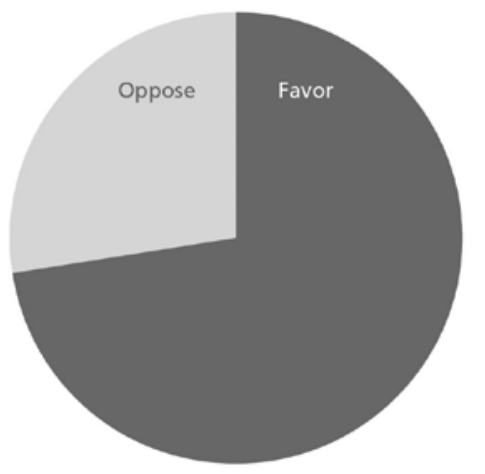

Laws to allow religious business owners to deny services to gays and lesbians

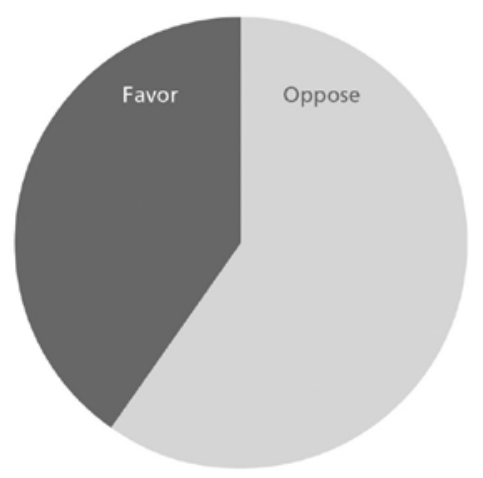

Figure 1. Nebraskans' support for legislation by type, 2018 
Nebraska is known for its conservative values. It has gone Republican in 19 of the past 20 presidential elections (the Democratic exception was Lyndon B. Johnson in 1964). Its failure to pass employment non-discrimination laws that recognize sexual orientation and gender identity appears to confirm a popular narrative: that citizens in red states oppose LGBT rights, and their opposition stems from conservative religious and political beliefs. However, in a recent representative survey of Nebraska residents, we found something different: varied but widespread support for LGBT rights.

These findings come from the 2018 Nebraska Annual Social Indicators Survey (NASIS), an omnibus mail survey conducted by the University of Nebraska- Lincoln's Bureau of Sociological Research. Nearly 1,000 adults living in the state responded, and the survey is weighted on age, gender, and state region in order to better resemble the $\mathrm{Ne}$ braskan population. The 2018 wave contained three questions about LGBT non-discrimination and religious liberty: whether respondents favor or oppose laws that protect gay men and lesbians from job discrimination, whether respondents favor or oppose laws that protection transgender individuals from job discrimination, and whether respondents favor or oppose religious business owners having the right to deny services to gay men and lesbians. Results indicate that about three out of four Nebraskans support legal protection for gays, lesbians, and transgender individuals from job discrimination and oppose religious business owners having the right to refuse service to gays and lesbians.

A common assumption in the U.S. is that both liberalness and queerness are associated with urban spaces. When it comes to Nebraskans' attitudes about legal protections for LGBT people, this is only partly true. Across the state, a clear majority of residents living in small towns, mid- and large- sized cities, and suburbs support nondiscrimination employment protection for LGBT people and oppose giving religious business owners the right to deny services to gays and lesbians. The highest levels of support are indeed among residents in cities and suburbs. Yet, among residents living towns with less than 10,000 people, $73 \%$ support protecting gays and lesbians from job discrimination and $67 \%$ support protecting transgender individuals, while $59 \%$ oppose allowing religious business owners to deny services to gays and lesbians. Residents who live in the "open country" (about 


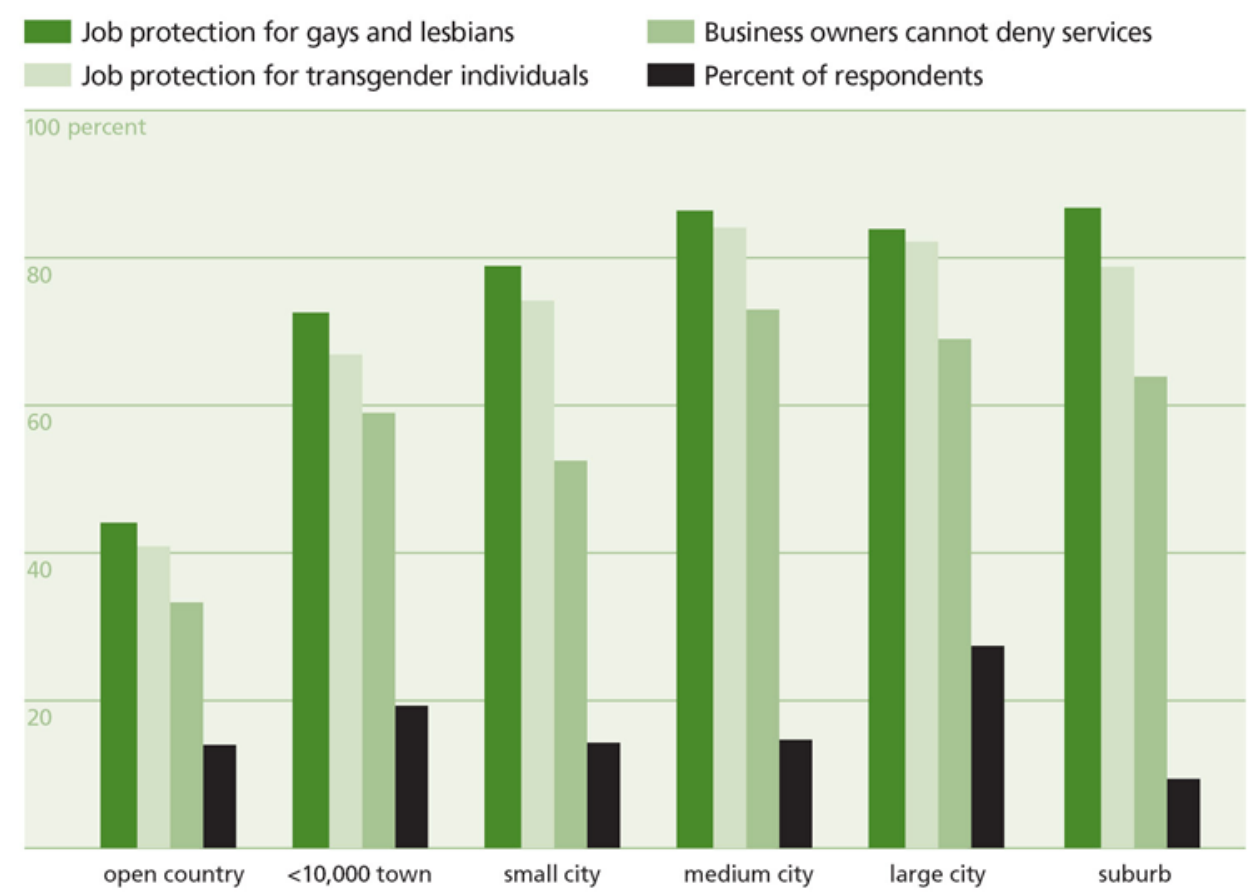

Figure 2. Nebraskans' support for LGBT rights by type of residence. Source: Nebraska Annual Social Indicators Survey 2018

$14 \%$ of the state's overall population) are the only group in which a majority opposes LGBT rights.

Consistent with other polls, we find that religiosity is negatively correlated with support for LGBT rights. Yet we still find surprising levels of support among religious respondents. The majority of Protestants (63-69\%) and Catholics (73-78\%) favor laws that protect gays, lesbians, and transgender individuals from job discrimination. Even among the most highly religious Nebraskans (those who attend church more than once a week), this is true (61\% favor laws protecting transgender individuals and $70 \%$ favor laws protecting gays and lesbians). Although $67 \%$ of these frequent church-goers believe that religious business owners should be allowed to deny services to gays and lesbians, that number drops to $46 \%$ for respondents who attend church "almost every week." About one of three Nebraskans who support non-discrimination protection for LGBT people also indicate support for religious exemption, indicating somewhat contradictory perspectives when it comes to religious and LGBT rights. 


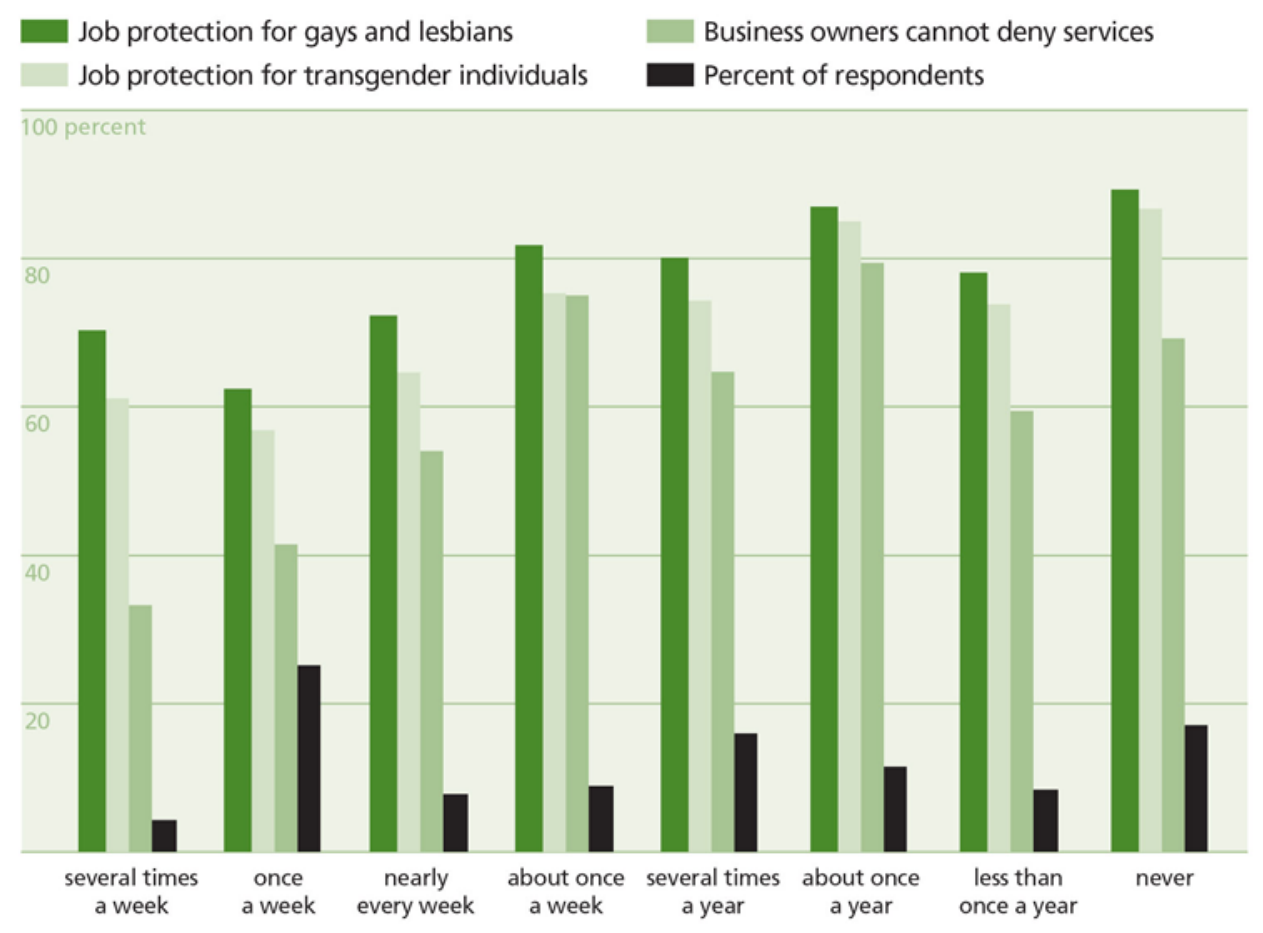

Figure 3. Nebraskans' support for LGBT rights by church attendance. Source: Nebraska Annual Social Indicators Survey 2018

Though there are clear political divides in Nebraskan attitudes about the rights of LGBT people, these are not as pronounced as polarizing political rhetoric may have us believe. An overwhelming majority (95\%) of Nebraskans who voted for Hillary Clinton in the 2016 President election support protection for gays, lesbians, and transgender individuals. Among Hillary voters, $89 \%$ oppose religious business owners being allowed to deny services to gays and lesbians. For two of the three policies, even a majority of Trump voters shows support for LGBT rights: $40 \%$ oppose religious business owners being allowed to deny services to gays and lesbians, $53 \%$ support employment protection for transgender individuals, and $63 \%$ support protection for gays and lesbians.

These patterns track national trends. In a recent, nationally representative survey, the Public Religion Research Institute (PRRI) found that nearly seven in ten (69\%) Americans support laws that would protect LGBT people from discrimination in housing, employment, and public accommodations. A Pew national survey found that only $32 \%$ 
Job protection for gays and lesbians Business owners cannot deny services

Job protection for transgender individuals

Percent of respondents

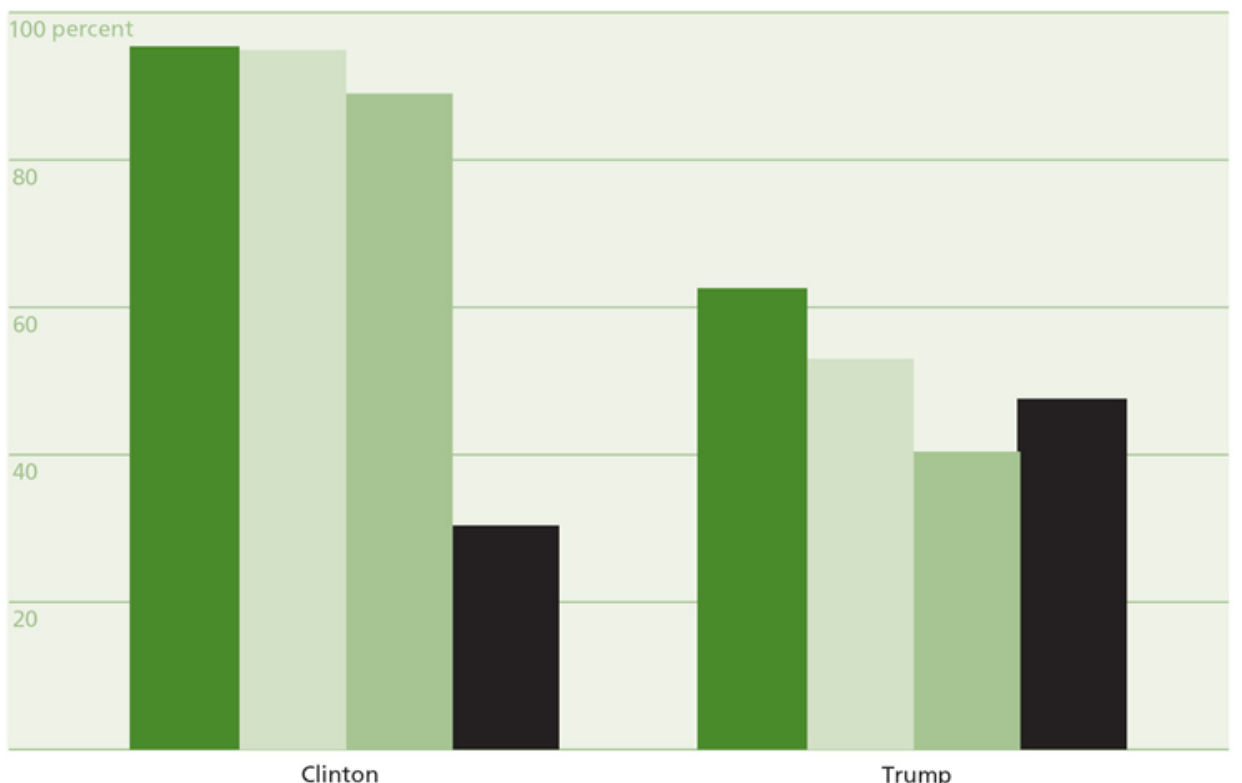

Figure 4. Nebraskans' support for LGBT rights by 2016 Presidential election voting. Source: Nebraska Annual Social Indicators Survey 2018

of Americans believe that small businesses should be able to refuse to provide services to gay and lesbian people on religious grounds. These figures suggest the majority of Americans support legal protections for LGBT people. Similar to the trends we found, the PRRI survey found majority support for employment non-discrimination across political party and religious affiliation as well as across all regions of the country.

These national trends of geography and support for LGBT rights resonate with research showing the increasingly geographical diversity of LGBT people. Contrary to assumptions about LGBT people primarily living in cities on the coasts, LGBT people are living and finding acceptance in states and regions assumed to be hostile (i.e., red states and small towns). Certainly, this does not mean that all LGBT people in Nebraska or elsewhere feel acceptance and security in their jobs or places of residence. In fact, some studies suggest that LGBT people living in states without non-discrimination laws have less positive, less supportive environments and experience more stress. 
Without federal legal mandates, state variation in legal protection for LGBT people is unlikely to change. We cannot know, for instance, whether refusals of services like those outlined in Mississippi's HB 1523 will be upheld in federal court, even if they may be protected by state law. The 2018 Supreme Court case, Masterpiece Cakeshop v. Colorado Civil Rights Commission, for instance, ruled in favor of the business owner who refused to bake a wedding cake for a same-sex couple. Yet the case set only a limited precedent: the ruling was based on the court's determination that the Colorado agency treated the baker's religious beliefs with hostility, leaving open the possibility for future rulings to side with LGBT people in similar cases. Next fall, the Supreme Court will hear its first cases to determine whether LGBT people are protected under the 1964 Civil Rights Acts. This may set a definitive precedent about employment non-discrimination and religious exemptions. Until then, state legislatures and courts must determine whether non-discrimination laws protecting LGBT people must offer religious exemptions and what those exemptions might be. Based on the data examined here, there is broad public support for actions that protect LGBT individuals in the workplace.

Kelsy Burke and Emily Kazyak are in the department of sociology at the University of Nebraska-Lincoln. Burke studies how religion and sexuality intersect to produce sets of politicized practices, ideologies, and identities. Kazyak studies stability and change in cultural and legal meanings of sexuality. 